\title{
Effectiveness of chest physiotherapy and pulmonary rehabilitation in patients with non-cystic fibrosis bronchiectasis: a narrative review
}

\author{
Sara Annoni ${ }^{1}$, Angela Bellofiore ${ }^{2}$, Elena Repossini ${ }^{3}$, Marta Lazzeri ${ }^{4}$, Antonello Nicolini ${ }^{5}$, Paolo Tarsia ${ }^{2}$ \\ ${ }^{1}$ Physical Medicine and Rehabilitation Unit, San Gerardo Hospital, Monza; ${ }^{2}$ Pulmonology and Adult Cystic Fibrosis \\ Center, Department of Internal Medicine, IRCCS Fondazione Ca' Granda Ospedale Maggiore Policlinico, Milan; ${ }^{3}$ Don \\ Gnocchi Foundation, Palazzolo Institute, Milan; ${ }^{4}$ Department of Cardiothoracic and Vascular Surgery, ASST Grande \\ Ospedale Metropolitano Niguarda, Milan; ${ }^{5}$ Respiratory Diseases Unit, Hospital of Sestri Levante, Genoa, Italy
}

\begin{abstract}
Respiratory physiotherapy and rehabilitation are important therapeutic options in non-cystic fibrosis bronchiectasis (NCFB). The aims of this review of clinical trials were to evaluate the safety and the effects on physiologic and clinical outcomes of airway clearance techniques (ACTs) and rehabilitation in NCFB patients, in comparison to usual care. The search was performed on March 2018 by using PubMed and PeDro databases. 33 studies were selected. The use of ACTs for NCFB were effective in increasing sputum volume although no benefit in quality of life (QoL) or pulmonary exacerbations were observed. There were no differences in effectiveness between the several techniques used. Humidification and saline inhalation were able to aid airway
\end{abstract}

Correspondence: Sara Annoni, ASST Monza, Physical Medicine and Rehabilitation Unit, San Gerardo Hospital, via Pergolesi 33, 20900 Monza, Italy.

Tel. +39.039.3392760584.

E-mail: sara.annoni@asst-monza.it

Key words: Bronchiectasis; airway clearance; humidification; saline inhalation; pulmonary rehabilitation.

Contributions: SA, AB, ER, ML, data acquisition, analysis and interpretation, manuscript drafting; AN, PT, manuscript critical revision for important intellectual content, English copyediting. All authors gave substantial contributions to work concept. All the authors have read and approved the final version of the manuscript and agreed to be accountable for all aspects of the work.

Conflicts of interest: The Authors declare no conflict of interest.

Received for publication: 3 June 2019.

Accepted for publication: 8 January 2020.

${ }^{\circ}$ Copyright: the Author(s), 2020

Licensee PAGEPress, Italy

Monaldi Archives for Chest Disease 2020; 90:1107

doi: 10.4081/monaldi.2020.1107

This article is distributed under the terms of the Creative Commons Attribution Noncommercial License (by-nc 4.0) which permits any noncommercial use, distribution, and reproduction in any medium, provided the original author(s) and source are credited. clearance. Hypertonic solution (HS) was more effective than isotonic solutions (IS) in improving expectoration and sputum viscosity. Pulmonary rehabilitation (PR) was found to be associated with short term benefits in exercise capacity, dyspnea and fatigue. Exercise training seems to improve quality of life and lower exacerbation rate, but long-term data are not available. Further studies are necessary to identify the most feasible long-term outcomes such as QoL and exacerbation rate.

\section{Introduction}

Bronchiectasis is an irreversible and progressive condition of the airways characterized by the presence of bronchial walls dilatation due to alterations in their structure. They may be congenital or more frequently acquired, secondary to a wide variety of conditions including lung infections, as severe pneumonia following measles, pertussis and tuberculosis. Chronic fibrous lung diseases such as those following abnormal pneumonia or inhalation of foreign bodies, harmful gases or particles, also predispose to the development of bronchiectasis. Congenital diseases such as cystic fibrosis, primitive ciliary dyskinesia, $\alpha-1$ antitrypsin deficiency, and immunodeficiencies can also result in bronchiectasis [1].

Bronchial walls dilatation usually involves segmental or subsegmental bronchioles, and can spread to one or more pulmonary lobes. These anatomical alterations combined with reduced airway clearance expose patients to the risk of bacterial colonization and recurrent infections [2]; the latter, in association with a chronic inflammatory reaction, can cause further airway damage, triggering a vicious circle. The small airways may also be involved as a consequence of proximal obstruction. In fact, in advanced stages of the disease peripheral spaces dilatation and deteriorated respiratory function are also present [3].

Patients with bronchiectasis may have heterogeneous clinical manifestations as repeated bronchial exacerbation episodes, with or without fever, increased cough and mucus production, hemoptysis, and daily production of significant amounts of mucus secretions. Some patients may have dry cough, with little or no expectoration. Bronchiectasis may be associated with other symptoms such as dyspnea, chest pain, fatigue, reduced exercise tolerance and reduced life expectancy [4-6]. Advanced stages of disease progress to the development of chronic respiratory failure and cor pulmonale-related heart failure [7].

Treatment of bronchiectasis is multifaceted and aims to control symptoms, improve life expectancy, prevent progressive pulmonary 
damage, reduce the number of exacerbations, and preserve pulmonary function. Recently, a therapeutic approach based on the severity of the disease has been promoted, involving the regular use of respiratory physiotherapy at all levels of the disease [8]. Respiratory physiotherapy goals include: facilitating secretions mobilization, optimizing ventilation efficiency, preserving or increasing exercise tolerance, reducing dyspnea and chest pain, improving patient knowledge about the disease, and optimizing physical performance of the subject and the management of the disease [7].

The aims of this review of clinical trials were to evaluate the safety and the effects on physiologic and clinical outcomes of airway clearance techniques and rehabilitation in patients with noncystic fibrosis bronchiectasis (NCFB), in comparison of usual care.

\section{Materials and Methods}

We searched in MEDLINE and PEDro databases, from 2005 to May 2018, with no language restriction. We also reviewed the references of retrieved articles for additional studies. We performed a literature search according to PRISMA statement (www.prismastatement.org).

Interventions evaluated were airway clearance techniques (ACTs), humidification, saline inhalation, and pulmonary rehabilitation (PR).

The interventions were compared with a control group (usual medical treatment), no treatment or sham treatment. Outcomes assessed were sputum volume, oxygen saturation, pulmonary function, number of pulmonary exacerbations, quality of life, respiratory symptoms, adverse events. The studies selected were clinical trials, comparative studies, controlled clinical trials and randomized controlled trials (RCT).

As search terms we used: "bronchiectasis" as keyword, which had to be present in the title or abstract of the articles(field). It was then linked via Boolean AND to other key words all in Mesh, inherent to all possible physiotherapy interventions, linked to each other by an OR operator. Through search builder, the final search strip was composed as follows: bronchiectasis[Title/Abstract] AND(physiotherapy OR physical therapy OR respiratory therapy OR exercise OR bronchial hygiene OR pulmonary rehabilitation OR chest therapy OR training OR hypertonic saline OR humidification).

The following filters were applied: humans, type of articles: clinical trial, comparative studies, controlled clinical trial, randomized controlled trial, publication between 1 January 2005 and 31 March 2018.

A subsequent search in the PEDro database allowed us to find additional studies. In this search the keyword "bronchiectasis" was again used, and had to be present in the abstract and title field within advanced search. Other fields were also completed: respiratory therapy (Therapy), clinical trials (Methods), published since 2005, match terms with AND. We found 23 articles.

\section{Results}

We identified 126 potentially relevant articles. Of these, 99 were excluded after the abstracts were read.

Finally, 33 studies were included in this review: 27 were found from primary searching and the others identified among the references. The process for selecting studies and exclusion criteria are displayed in Figure 1.

A total of 33 articles were included as they addressed the three main areas of intervention: tracheo-bronchial clearance (20 studies), airway humidification and saline inhalation (6 studies), and exercise (7 studies).

\section{Bronchial airway clearance}

ACTs are now recommended in bronchiectasis aimed at improving airway clearance [9-11]. Only in recent years we have witnessed a gradual increase in specific studies on NCFB.

The first studies were focused on the direct comparison of two main techniques: Oscillatory Positive Expiratory Pressure techniques (O-PEP) (Flutter and Acapella), and controlled breathing techniques [Active Cycle of Breathing Technique $(\mathrm{ACBT})]$ and Breathing Control $(\mathrm{BC})$ with or without posture changes (Table 1). Three crossover studies [12-14], and 2 RCTs $[15,16]$ have showed similar outcomes in respiratory function parameters and sputum weight. There were no significant differences in efficacy between the techniques proposed, both in acute $[15,16]$ and chronic patients [12-14]. In a single study the forced expiratory volume in $1 \mathrm{~s}\left(\mathrm{FEV}_{1}\right)$ improved with flutter $(p<0.03)$ [12]; in another study ACBT associated with posture changes was associated with improved secretions drainage than flutter [14]. Several studies have found that O-PEP device was the preferred technique both in chronic (in $65 \%, 70 \%$ and $44 \%$, respectively) [12-14] and in acute patients, because it was considered more effective (Flutter $v s \mathrm{BC} \mathrm{p}=0.011$ ) [15]. However, no statistically significant difference in tolerance and duration of treatment was observed (Acapella vs ACBT p<0.06) [16]. The main limitations in comparing the results of these studies are the use of different scales for subjective measurements (chronic respiratory questionnaire (CRQ), Borg dyspnea, visual analogic scale (VAS), Likert Scale). Also, different application techniques time ranging from single daily treatment to twice or more times per day, for a total time that never exceeded 4 weeks have been used $[13,14]$.

In 2009, Murray proposed a three-month crossover study to evaluate the effectiveness of regular chest physiotherapy [17]. There was a significant difference in medium to long term sputum volume using Acapella twice per day compared to the group not treated with airway clearance. The increase in the sputum volume was associated with higher exercise tolerance (Incremental Shuttle Walking Test (ISWT) $\mathrm{p}<0.001)$ and improved quality of life (QoL) [Leicester Cough Questionnaire (LCQ) $\mathrm{p}<0.002$, Saint George Respiratory Questionnaire (SGRQ) $\mathrm{p}<0.005$ ]. However, there were no spirometric parameters and number of exacerbations improvement.

Guimarães performed a crossover-controlled study [18], and although there was a single treatment session for each technique (Expiration Lente Totale Glotte Ouverte en infraLateral (ELTGOL) and flutter), static volumes significantly decreased after only 15 minutes compared to the control group in the treatment with ELTGOL [total lung capacity (TLC) $9.66 \%$, Functional residual capacity (FRC) $14.48 \%$, residual volume (RV) $18.72 \%$ ) and with Flutter (TLC $18.27 \%$, FRC $25.81 \%$ and RV 29.55\%]. The authors concluded that these techniques were equally useful in reducing the degree of hyperinflation in obstructive syndromes. Moreover, the ELTGOL technique allowed faster secretions drainage than the flutter did $(\mathrm{p}<0.05)$. The first study of long-term effectiveness of ELTGOL in cleaning secretions was described in a recent randomized placebo-controlled trial [19]. Performance of the 
ELTGOL technique twice-daily over a 1 -year period increased overall 24-h sputum volume (during first intervention and $24 \mathrm{~h}$ later) by $17 \mathrm{~mL}$ compared to placebo $(\mathrm{p} \leq 0.001)$. The trial reported lower exacerbation rate $(\mathrm{p}=0.042)$, an improvement in QoL (SGRQ $\mathrm{p}<0.001$ ), and a reduction in the impact of coughing (LCQ $\mathrm{p}<0.001)$. This study is the first long-term randomized controlled trial of an ACT. Finally, two recent studies have analyzed the efficacy and comfort of ACBT compared to postural drainage (PD), concluding that there were no significant differences in sputum volume [20]; nevertheless, ACBT was the preferred technique [21].

Several studies have analyzed the use of alternative techniques to enhance airway clearance (Table 2). Naraparaju compared Acapella with an Inspiratory Muscle Training instrument (IMT), concluding on the superiority of the O-PEP device with a sputum amount of $7.16 \pm 1.12 \mathrm{~mL}$ vs $6.4 \pm 1.08 \mathrm{ml}$ ( $\mathrm{p}=0.014)$ [22]. A study on a population of 78 patients with chronic obstructive pulmonary disease (COPD) and 20 with bronchiectasis evaluated the efficacy of temporary PEP (T-PEP) on several outcomes. A statistically significant improvement in inspiratory capacity (IC) was observed in the T-PEP group compared to the control group, in which only manual techniques were performed [23].
Limitations in this study were the treatment time (20 min for manual treatment vs $20 \mathrm{~min}+15 \mathrm{~min}$ for the T-PEP group) and population data (bronchiectasis patients were not described separately in the study). Herrero-Cortina et al. [24] investigated the efficacy of T-PEP compared to other manual techniques [autogenic drainage (AD) and ELTGOL] in a more homogeneous group of patients. The authors emphasized the equal effectiveness of the three techniques in draining secretions over $24 \mathrm{~h}$ after physiotherapy. Furthermore, a progressively lower production of sputum in daily life compared to baseline $(\mathrm{p}<0.001)$ was observed. Whereas AD and ELTGOL were associated with faster sputum drainage, sometimes within the same session, T-PEP appeared capable of generating a constant drainage, even after the application. The study of D'Abrosca et al. [25] confirmed the efficacy of T-PEP on pulmonary function parameters. The author additionally observed a reduction in oxygen requirement among patients on long-term oxygen therapy compared to the group treated with PEP Mask.

A recent RCT investigated the short-term efficacy of high frequency chest wall oscillation (HFCWO). HFCWO applied for $30 \mathrm{~min}$ twice per day at a frequency of $13-15 \mathrm{~Hz}$ was compared with a commonly used ACTs (PEP, ELTGOL) and with medical therapy

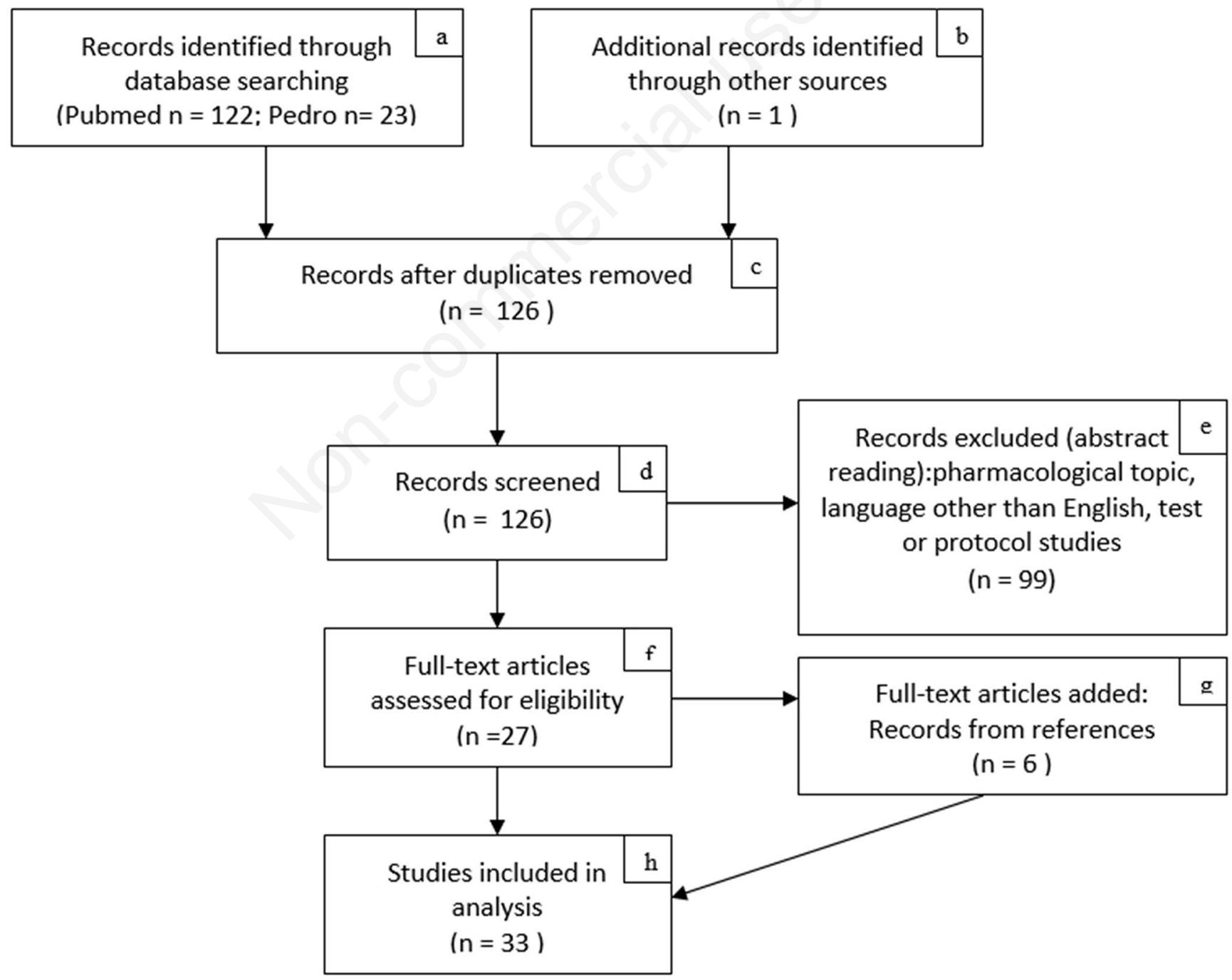

Figure 1. Flowchart illustrating the process for selecting studies and exclusion criteria. 
Table 1. Studies evaluating the use of oscillating positive expiratory pressure (PEP) and controlled breathing techniques (ACBT, BC, ELTGOL).

\begin{tabular}{|c|c|c|c|c|c|c|}
\hline Reference & $\begin{array}{l}\text { No. of patients } \\
\left(F E V_{1}\right)\end{array}$ & Study design & \multicolumn{2}{|l|}{ Treatment } & Outcomes & $\begin{array}{l}\text { Significant } \\
\text { results }\end{array}$ \\
\hline Thompson 2002 [12] & $17(70 \%)$ & $\begin{array}{l}\text { Crossover } \\
4 \text { weeks } \\
\text { (no wash out) }\end{array}$ & \multicolumn{2}{|c|}{$\begin{array}{l}\text { Twice per day until no further sputum to expectorate } \\
\text { Information sheets } \\
\text { FET after both techniques } \\
\text { PD in } 2 \text { positions chosen by therapist as needed } \\
\text { Flutter device } \\
\begin{array}{l}\text { ACBT } \\
\text { TEE, BC, HUFF }\end{array}\end{array}$} & $\begin{array}{l}\text { Spirometric } \\
\text { parameters, } \\
\text { sputum weight, } \\
\text { Borg dyspnea, } \\
\text { CRQ }\end{array}$ & $\begin{array}{l}\uparrow \mathrm{FEV}_{1} \text { after } \\
\text { Flutter } \\
65 \% \text { of patients } \\
\text { preferred } \\
\text { Flutter device }\end{array}$ \\
\hline Patterson 2005 [13] & $20(64 \%)$ & $\begin{array}{l}\text { Crossover } \\
2 \text { days } \\
\text { (no wash out) }\end{array}$ & \multicolumn{2}{|l|}{$\begin{array}{l}1 \text { time per day - lasting up to } 30 \\
\text { Medication at least } 1 \text { hour befo } \\
\text { PD in } 2 \text { positions chosen by the } \\
\text { Acapella+PD } \\
\text { Individual Acapella setting } \\
10 \text { inspirations up to } 3 / 4 \mathrm{MIC} \text {, } \\
2-3 \text { sec breath hold, active } \\
\text { exhalation } 2-3 \text { HUFF or cough }\end{array}$} & $\begin{array}{l}\text { Spirometric } \\
\text { parameters, } \\
\mathrm{O}_{2} \text { saturation, } \\
\text { Sputum weight, } \\
\text { Dyspnea (VAS) }\end{array}$ & $\begin{array}{l}70 \% \text { of patients } \\
\text { preferred } \\
\text { Acapella }\end{array}$ \\
\hline Eaton 2007 [14] & $36(57.8 \%)$ & $\begin{array}{l}\text { Crossover } \\
3 \text { days } \\
\text { ( } 2 \text { days wash } \\
\text { out) }\end{array}$ & \multicolumn{2}{|c|}{ 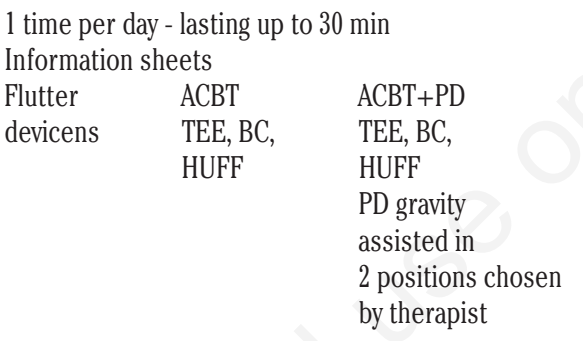 } & $\begin{array}{l}\text { Spirometric } \\
\text { parameters, } \\
\mathrm{O}_{2} \text { saturation, } \\
\text { sputum weight } \\
\text { and volume, } \\
\text { timing of sessions, } \\
\text { Likert scale }\end{array}$ & $\begin{array}{l}\uparrow \text { sputum weight } \\
\text { and volume after } \\
\text { ACBT+PD } \\
44 \% \text { of patients } \\
\text { preferred Flutter } \\
\text { device }\end{array}$ \\
\hline Tsang 2003 [15] & $15(41 \%)$ & RCT 1 week & \multicolumn{2}{|c|}{$\begin{array}{lll}3 \text { times per day - lasting } 15 \mathrm{~min} & \text { Spirometric } \\
\text { BC5 deep } & \text { BC+PD2 } & \text { BC+flutter device } \\
\text { inspirations } & \text { positions } & \text { Patient in sitting } \\
\text { with relaxed } & \text { gravity } & \text { position } \\
\text { expiration } & \text { assisted } & \text { Normal inspiration } \\
\text { every 3 min } & \text { chosen by } & \text { with active } \\
& \text { therapist, } & \text { exhalation } \\
& \text { lasting 7.5 } & \text { through the } \\
& \text { min each } & \text { device } \\
\end{array}$} & $\begin{array}{l}\downarrow \text { bronchial } \\
\text { parameters, } \\
\text { Heart rate, } \\
\mathrm{O}_{2} \text { saturation, } \\
\text { Sputum weight, } \\
\text { Bronchial } \\
\text { encumbrance } \\
\text { (VAS) }\end{array}$ & $\begin{array}{l}\text { encumbrance } \\
\text { (VAS) after BC+ } \\
\text { flutter }\end{array}$ \\
\hline Patterson 2007 [16] & $\begin{array}{l}20 \\
\text { Acute exacerbation } \\
(65 \%)\end{array}$ & RCT 14 days & \multicolumn{2}{|c|}{$\begin{array}{ll}2 \text { times per day - lasting up to } 30 \text { min } \\
\text { Acapella } & \text { Usual (ACBT) } \\
\text { Individual Acapella } & \text { Usual technique } \\
\text { setting } & \text { review with therapist }\end{array}$} & $\begin{array}{l}\text { Spirometric } \\
\text { parameters, } \\
\mathrm{O}_{2} \text { saturation, } \\
\text { sputum weight } \\
\text { and volume, } \\
\text { dyspnea (VAS), } \\
\text { timing of sessions, } \\
\text { Borg dyspnea }\end{array}$ & $\begin{array}{l}\uparrow \text { Acceptability of } \\
\text { sessions with } \\
\text { Acapella }\end{array}$ \\
\hline Murray 2009 [17] & $20(75 \%)$ & $\begin{array}{l}\text { Crossover } \\
3 \text { months } \\
\text { (1 month } \\
\text { wash out) }\end{array}$ & \multicolumn{2}{|l|}{$\begin{array}{l}\text { Acapella } \\
2 \text { times per day lasting } \\
20-30 \text { min } \\
\text { Device set at position } 310 \\
\text { inspirations up to } 3 / 4 \text { MIC, } \\
\text { breath hold, active exhalation } \\
\text { 2-3 HUFF or cough }\end{array}$} & $\begin{array}{l}\text { Spirometric } \\
\text { parameters, MIP, } \\
\text { MEP, sputum } \\
\text { volume, } \\
\text { ISWT, SGRQ, LCQ }\end{array}$ & $\begin{array}{l}\uparrow \text { LCQ, sputum } \\
\text { volume and ISWT } \\
\text { after Acapella }\end{array}$ \\
\hline Guimarães 2012 [18] & $10(53 \%)$ & $\begin{array}{l}\text { Crossover } \\
3 \text { days } \\
\text { (1 week } \\
\text { wash out) }\end{array}$ & \multicolumn{2}{|l|}{ 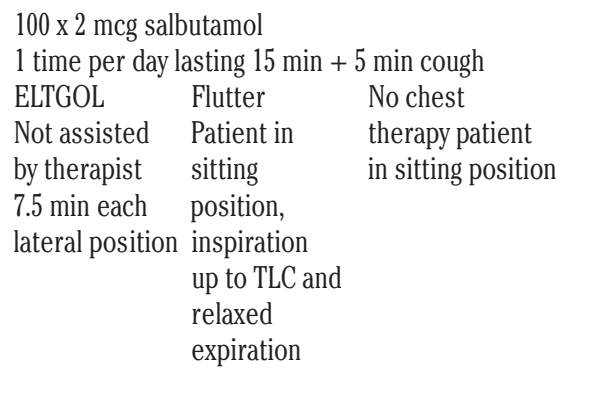 } & $\begin{array}{l}\text { Spirometric } \\
\text { parameters, } \\
\text { Sputum volume }\end{array}$ & $\begin{array}{l}\downarrow R V \text {, FRC, TLC } \\
\text { after ELTGOL and } \\
\text { after flutter } \\
\text { compared to } \\
\text { control group } \\
\\
\uparrow \text { sputum volume } \\
\text { after ELTGOL } \\
\downarrow \text { IC/TLC } \\
\text { after flutter }\end{array}$ \\
\hline
\end{tabular}

To be continued on next page. 
alone (control group). Both active treatment groups were associated with a significant increase in the amount of sputum, and a reduction of symptoms and scores related to health status in comparison to the control group. Direct comparison between the two active treatment groups demonstrated the superior efficacy of HFCWO in reducing inflammatory parameters, and in improving forced vital capacity (FVC) and $\mathrm{FEV}_{1}$ [26].

In another study, intrapulmonary percussive ventilation (IPV) was compared with conventional therapy: PD and forced expiration technique (FET). In both groups there was no significant change in oxygen saturation, whereas a reduction of respiratory rate, an improvement in dyspnea and an increased amount of sputum were observed in the group treated with IPV [27].

Furthermore, four crossover studies (Table 3) analyzed the direct mechanical effects of O-PEP on mucus and airway resistance. Valente [28] investigated the effect of oscillating waves comparing the flutter with a "sham flutter" obtained by removing the metal ball and partially blocking the holes to maintain the PEP effect. There were no significant changes in the displacement velocity and mucosal adhesion after 20 and 40 minutes of treatment. Other recent studies have used sham flutter as a method of comparison, with different results from the former study. Tambascio highlighted that mechanical oscillations were able to modify mucus rheology by reducing adhesive strength $(p<0.05)$ [29]. Figueiredo observed that the use of vibrations decreased bronchial tree resistances, particularly distal resistances, improving ventilation distribution $(p<0.05)$ in patients with hypersecretive bronchiectasis [30]. Ramos has showed that

Table 1. Continued from previous page.

\begin{tabular}{|c|c|c|c|c|c|}
\hline Reference & $\begin{array}{l}\text { No. of patients } \\
\left(\mathrm{FEV}_{1}\right)\end{array}$ & Study design & Treatment & Outcomes & $\begin{array}{l}\text { Significant } \\
\text { results }\end{array}$ \\
\hline Munoz 2018 [19] & $44(60 \%)$ & RCT1 year & $\begin{array}{l}2 \text { times per day lasting } 15 \mathrm{~min} \text { for each lung affected } \\
\begin{array}{ll}(1 \text { lung = } 15 \mathrm{~min} ; 2 \text { lungs = } & 30 \mathrm{~min}) \\
\text { ELTGOL } & \text { Placebo } \\
\text { Not assisted by } & \text { Upper-limb stretching } \\
\text { therapist } & \text { exercises, involving } \\
& \text { the brachial biceps, } \\
& \text { triceps, deltoids, } \\
& \text { pectoralis major } \\
& \text { and latissimus dorsi }\end{array}\end{array}$ & $\begin{array}{l}\text { Sputum volume } \\
\text { after 24h and after } \\
\text { 1-3-6-9-12 months, } \\
\text { Inflammatory } \\
\text { markers, } \\
\text { number of } \\
\text { exacerbations, } \\
\text { time to the first } \\
\text { exacerbation, } \\
\text { LCQ and SGRQ } \\
\text { at } 6 \text {-12 months, } \\
\text { Sputum typesetting, } \\
\text { mMRC, FEV1 } \\
\text { Exercise capacity, } \\
\text { Treatment } \\
\text { adherence } \\
\text { Side effects }\end{array}$ & $\begin{array}{l}\uparrow \text { sputum volume } \\
\text { after ELTGOL at } \\
\text { all times } \\
\downarrow \text { number of } \\
\text { exacerbations } \\
\text { after ELTGOL } \\
\uparrow \text { LCQ after } \\
\text { ELTGOL at all } \\
\text { times } \\
\downarrow \text { SGRQ after } \\
\text { ELTGOL at all } \\
\text { times } \\
\uparrow \text { Treatment } \\
\text { adherence with } \\
\text { ELTGOL }\end{array}$ \\
\hline Abdelhalim 2015 [20] & $\begin{array}{l}30 \text { acute } \\
\text { exacerbation } \\
(55 \%)\end{array}$ & $\begin{array}{l}\text { RCT14 days } \\
\text { PD gravity } \\
\text { assisted }\end{array}$ & $\begin{array}{ll}2 \text { times per day - lasting } 15-20 \mathrm{~min} \\
\mathrm{ACBT}+\mathrm{PDTEE}+\mathrm{BC}+\mathrm{HUFF} & \mathrm{CPT}+\mathrm{PD} \\
& \text { Diaphragmatic } \\
& \text { breathing, clapping }\end{array}$ & $\begin{array}{l}\text { LCQ, mMRC, } \\
\text { Spirometric } \\
\text { parameters, } \\
\text { Blood gas analysis, } \\
\text { sputum volume }\end{array}$ & $\begin{array}{l}\uparrow \mathrm{LCQ} \text { e } \uparrow \mathrm{PaO}_{2} \\
\text { after ACBT } \\
\uparrow \text { Blood gas } \\
\text { analysis and } \\
\text { sputum volume } \\
\text { after CPT } \\
\\
\text { Compared to basal } \\
\text { values both } \\
\text { techniques: } \\
\downarrow \text { mMRC } \\
\uparrow \text { selected } \\
\text { spirometric } \\
\text { parameters } \\
\uparrow \text { Blood gas analysis }\end{array}$ \\
\hline Syed 2009 [21] & 35 (ns) & $\begin{array}{l}\text { Crossover } \\
2 \text { days( } 12 \text { hours } \\
\text { wash out) }\end{array}$ & $\begin{array}{ll}4 \text { times per day - lasting up to } 30 \text { min } \\
\text { PD in different positions } & \\
\text { ACBT+PD } & \text { CPT+PD } \\
\text { TEE, BC, HUFF } & \text { Vibrations, clapping, } \\
& \text { cough, TEE }\end{array}$ & $\begin{array}{l}\text { Spirometric } \\
\text { parameters, } \\
\text { sputum weight } \\
\text { and volume, } \\
\text { comfort (VAS) }\end{array}$ & $\begin{array}{l}\uparrow \text { comfort after } \\
\text { ACBT }\end{array}$ \\
\hline
\end{tabular}

$\uparrow$, increase, improvement; $\downarrow$, only decrease, no negative meaning or worsening; FET, forced expiration technique; ACBT, active cycle of breathing technique; BC, breathing control; TEE, thoracic expansion exercise; HUFF forced expiration with open glottis; PD, postural drainage*; RTC, randomised controlled trial; CRQ, chronic respiratory questionnaire; FEVl, forced expiration volume at first second; VAS, visual analogic scale; MIC, maximum inspiratory capacity; CPT , chest physiotherapy; LCQ, Leicester cough questionnaire; mMRC, modified Medical Research Council dyspnea scale; PaO2, oxygen partial pressure; MIP, maximum inspiratory pressure; MEP, maximum expiratory pressure; ISWT, incremental shuttle walking test; SGRQ, Saint George respiratory questionnaire; ELTGOL, expiration lente totale glotte ouverte en infralateral; TLC, total lung capacity; RV, residual volume; FRC, functional residual capacity; IC, inspiratory capacity; ns, not specified. *This technique is often poorly described. When not specified positioning may be referred to change in regional lung ventilation or may be only turning. Please refer to authors. 
manual percussion and forced expiration with open glottis (HUFF) might be effective in improving the drainage of viscous-elastic secretions, but only after application times longer than 60-90 min [31].

\section{Interventions aiding airway clearance}

In current clinical practice, humidification and saline (isotonic

Table 2. Studies evaluating the use of techniques other than usual PEP (IMT, T-PEP, HFCWO, IPV).

\begin{tabular}{|c|c|c|c|c|c|c|}
\hline Reference & $\begin{array}{l}\text { No. of patients } \\
\left(F E V_{1}\right)\end{array}$ & Study design & \multicolumn{2}{|l|}{ Treatment } & Outcomes & $\begin{array}{l}\text { Significant } \\
\text { result }\end{array}$ \\
\hline Naraparaju 2010 [22] & $\begin{array}{l}30(44.5 \%) \\
\text { Sputum }>30 \mathrm{ml} \\
\text { per day }\end{array}$ & $\begin{array}{l}\text { Crossover } 2 \text { days } \\
\text { (no wash out) }\end{array}$ & \multicolumn{2}{|c|}{$\begin{array}{ll}1 \text { time per day } & \\
\text { Medication at least } 1 \text { hour before treatment } \\
\text { Acapella10 inspirations } & \text { IMT } \\
\text { up to } 3 / 4 \text { MIC, } 2-3 \text { sec breath } & \text { Setting } 80 \% \text { of MIP } \\
\text { hold, active exhalation } & 10 \text { inspirations from } \\
\text { through device } & \text { RV to TLC, 2-3 sec } \\
\text { HUFF or cough every } & \text { breath hold, active } \\
5 \text { breaths } & \text { exhalation to FRC } \\
& \text { HUFF or cough every } \\
& 5 \text { breaths }\end{array}$} & $\begin{array}{l}\text { Sputum volume, } \\
\text { timing of session, } \\
\text { patient preference }\end{array}$ & $\begin{array}{l}\uparrow \text { Sputum volume } \\
\text { after Acapella }\end{array}$ \\
\hline Venturelli 2012 [23] & $\begin{array}{l}98(56 \%) \\
\text { only } 20 \text { out of } 98 \\
\text { were NCFB }\end{array}$ & RCT 10 days & \multicolumn{2}{|l|}{$\begin{array}{l}2 \text { times per day } \\
\text { Training with therapist } \\
\text { Manually assisted } \\
\text { techniques + T-PEP } \\
20 \text { min + } 15 \text { min T-PEP }\end{array}$} & $\begin{array}{l}\text { Spirometric } \\
\text { parameters, } \\
\mathrm{MIP}, \mathrm{MEP}, \mathrm{PaO}_{2} / \mathrm{FiO}_{2} \text {, } \\
\text { sputum volume, } \\
\text { Sputum density } \\
\text { and purulence, } \\
\text { bronchial } \\
\text { encumbrance (VAS) }\end{array}$ & $\begin{array}{l}\uparrow \text { FEVl, FVC, CV } \\
\text { after T-PEP } \\
\uparrow \text { IC after T-PEP }\end{array}$ \\
\hline Herrero 2016 [24] & $29(63 \%)$ & $\begin{array}{l}\text { Crossover } \\
3 \text { weeks(1 week } \\
\text { wash out) }\end{array}$ & \multicolumn{2}{|c|}{$\begin{array}{ll}3 \text { times per week - lasting } 40 \text { min } \\
\text { AD } \quad \text { ELTGOL } & \text { T- PEP } \\
\text { Breathing from Assisted by } & \text { Slow breathing } \\
\text { lower through therapist } & \text { through the device } \\
\text { higher lung } & \\
\text { volume levels } & \\
\text { with open } & \\
\text { glottis. } & \\
\text { Not assisted } & \end{array}$} & $\begin{array}{l}\text { Spirometric } \\
\text { parameters, } \\
\mathrm{O}_{2} \text { saturation, } \\
\text { Heart rate, } \\
\text { Sputum weight } \\
\text { after } 40 \text { min and } \\
24 \text { hours, } \\
\text { LCQ, } \\
\text { Likert scale } \\
\text { to T-PEP } \\
\text { LCQ after } \\
\text { ELTGOL }\end{array}$ & $\begin{array}{l}\downarrow \text { Sputum weight } \\
\text { during wash out } \\
\text { compared to basal } \\
\text { values } \\
\uparrow \text { sputum weight } \\
\text { during session } \\
\text { with AD and } \\
\text { ELTGOL compared }\end{array}$ \\
\hline D’Abrosca 2017 [25] & $162(51 \%)$ & $\begin{array}{l}\text { Retrospective } \\
10 \text { days }\end{array}$ & \multirow{3}{*}{\multicolumn{2}{|c|}{ 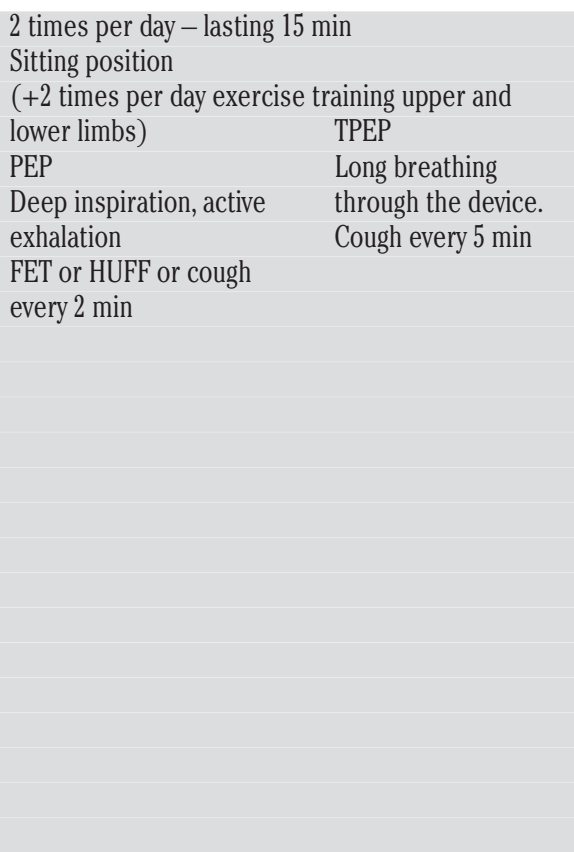 }} & $\begin{array}{l}\text { Spirometric } \\
\text { parameters, } \\
\text { Blood gas analysis }\end{array}$ & $\begin{array}{l}\uparrow F V C, \mathrm{FEV}_{1}, \mathrm{PEF}, \\
\text { blood gas analysis } \\
\text { (except } \mathrm{CO}_{2} \text { ) after } \\
\text { both techniques } \\
\text { compared to basal } \\
\text { values }\end{array}$ \\
\hline & & & & & & $\begin{array}{l}\text { Patients with } \\
\text { emphysema and/or } \\
\text { long-time oxygen } \\
\text { therapy } \downarrow \text { usual } \mathrm{FiO}_{2} \\
\text { after T-PEP } \\
\text { } \text { usual } \mathrm{FiO}_{2} \text { after } \\
\text { PEP } \\
\text { Patients with } \\
\text { mechanical } \\
\text { ventilation } \\
\uparrow \mathrm{FEF}_{50} \text { after } \\
\text { T-PEP }\end{array}$ \\
\hline & & & & & & $\begin{array}{l}\text { Other patients } \\
\uparrow \mathrm{PaO}_{2} / \mathrm{FiO}_{2} \text { after } \\
\text { T-PEP }\end{array}$ \\
\hline
\end{tabular}

To be continued on next page. 
or hypertonic) administration are used to modify mucus characteristics and improve airway clearance.

\section{Humidification}

In 1992, Conway [32] published a study evaluating airway clearance by radio-marking aerosol after a session of cold humidification with sterile water. Significant results were found for sputum weight $(\mathrm{p}<0.05)$ and radio-marking clearance $(\mathrm{p}<0.05)$.

More recently, several studies have evaluated the effects of warm air humidification in subjects with bronchiectasis (Table 4). In the first observational study, 14 patients were enrolled for 7 days of home-warming humidification lasting $3 \mathrm{~h}$ a day, with a high-flow system that supplied water vapor air at $37^{\circ} \mathrm{C}$ at a flow of 20 to 25 $1 /$ min through a special nasal-cannula. The study measured tracheobronchial clearance through the retention of a radioactive tracer monitored at 6 and 24 hours, and assessed pulmonary function. After the treatment, an increase in mucosal clearance was observed $(\mathrm{p}=0.007)[33]$.

In 2012, Rea and colleagues [34] evaluated the effects of one year-treatment using the same high-flow system from the former study. They recruited 108 patients, including 73 patients with COPD and 45 with bronchiectasis. The treatment group performed active humidification using high flow nasal cannula (HFNC) $2 \mathrm{~h}$ per day, the control group received usual care according to Australian-Asian guidelines [35]. There were no statistically significant differences between the two groups in the exacerbation rate, number of admissions, distance walked during 6 minutes walking test (6MWT) and inflammatory markers; whereas statistically significant differences were found in the total days of exacerbations, number of subjects who did not show exacerbations, $\mathrm{FEV}_{1}$ and FVC at 6 and 12 months, antibiotic therapy consumption, and SGRQ scores.

\section{Inhalation of nebulized saline solution}

In the study published by Kellett and coll. four interventions with different humidification techniques and timing were compared. Saline solutions, isotonic solution (IS) and hypertonic solution (HS), have proved to be significantly more effective in increasing sputum amount, reducing viscosity, and facilitating expectoration compared to ACBT alone. HS was significantly more efficient than IS regarding the weight of produced sputum, viscosity and ease of sputum production [36].

Subsequently, the same authors conducted a crossover study that lasted 9 months comparing the use of IS at $0.9 \%$ to HS at $7 \%$. A significant improvement in $\mathrm{FEV}_{1}(\mathrm{p}<0.01)$ and $\mathrm{FVC}(\mathrm{p}<0.01)$ in the

Table 2. Continued from previous page.

\begin{tabular}{|c|c|c|c|c|c|c|}
\hline Reference & $\begin{array}{l}\text { No. of patients } \\
\left(F E V_{1}\right)\end{array}$ & Study design & Treatment & & Outcomes & $\begin{array}{l}\text { Significant } \\
\text { result }\end{array}$ \\
\hline Nicolini 2013 [26] & $30(60 \%)$ & RCT2 weeks & $\begin{array}{ll}2 \text { times per day } & \text { CPT } \\
\text { HFCWO } & 45 \text { min } \\
30 \text { min } 13-15 \mathrm{~Hz} & \text { ELTGOL, } \\
\text { Patient in } & \text { PEP mask, } \\
\text { sitting position } & \text { PEP bottle, } \\
& \text { Acapella }\end{array}$ & $\begin{array}{l}\text { Control no chest } \\
\text { therapy }\end{array}$ & $\begin{array}{l}\text { Spirometric } \\
\text { parameters, } \\
\text { MIP, MEP, } \\
\text { Blood gas analysis } \\
\text { Sputum cellularity } \\
\text { Sputum volume } \\
\text { BCSS } \\
\text { CAT } \\
\text { mMRC }\end{array}$ & $\begin{array}{l}\uparrow \text { sputum volume, } \\
\text { BCSS, CAT, mMRC } \\
\text { after CPT compared } \\
\text { to control group } \\
\text { } \text { sputum volume, }_{\text {BCSS, CAT, }} \\
\text { mMRCFEV }, \text { FVC, } \\
\text { RV, TLC, MIP, MEP, } \\
\text { sputum cellularity } \\
\text { after HFCWO } \\
\text { compared to } \\
\text { control group } \\
\text { 个sputum volume, } \\
\text { BCSS, CAT, FEV } \\
\text { FVC after HFCWO } \\
\text { compared to CPT }\end{array}$ \\
\hline Paneroni 2011 [27] & $22(53 \%)$ & $\begin{array}{l}\text { Crossover } \\
2 \text { days } \\
\text { (no wash out) }\end{array}$ & $\begin{array}{l}1 \text { time per day - lasting } 30 \text { min } \\
\text { Cough after treatment sessior } \\
\text { IPV } \\
\text { Patient in sitting position, } \\
2 \text { phases low pressure high } \\
\text { frequency, } 1 \text { phase high } \\
\text { pressure low frequency }\end{array}$ & $\begin{array}{l}\text { CPT } \\
\text { PD in } 3 \text { position with } \\
\text { FET, percussion and } \\
\text { clapping set in a } \\
\text { cycle }\end{array}$ & $\begin{array}{l}\mathrm{O}_{2} \text { saturation, } \\
\text { heart rate, } \\
\text { respiratory rate, } \\
\text { sputum volume } \\
\text { and weight, } \\
\text { bronchial } \\
\text { encumbrance } \\
\text { (VAS), } \\
\text { discomfort and } \\
\text { dyspnea (VAS) }\end{array}$ & $\begin{array}{l}\downarrow \text { Respiratory rate, } \\
\text { dyspnea and } \\
\text { discomfort with }\end{array}$ \\
\hline
\end{tabular}

$\uparrow$, increase, improvement; $\downarrow$, only decrease, no negative meaning or worsening; ns, not specified; RTC, randomised controlled trial; NCFB, non-cystic fibrosis bronchiectasis; IMT, inspiratory muscle training; T-PEP, temporary PEP (called also UNIKO); HFCWO, High frequency chest wall oscillation; IPV, intrapulmonary percussive ventilation; HUFF, forced expiration with open glottis; CPT , chest physiotherapy; PD, postural drainage; FET, forced expiration technique; ELTGOL, expiration lente totale glotte ouverte en decubitus lateral; VAS, visual analogic scale; BCSS, breathlessness, cough and sputum scale; CAT, COPD assessment test; mMRC, modified Medical Research Council dyspnea scale; QoL, Quality of Life; AD, autogenic drainage; MIC, maximum inspiratory capacity; MIP, maximum inspiratory pressure; MEP, maximum expiratory pressure; RV, residual volume; TLC, total lung capacity; FRC, functional residual capacity; FEV , forced expiration volume at first second; FVC, forced vital capacity; CV, current volume; IC, inspiratory capacity; RV, residual volume; TLC, total lung capacity; PEF, peak expiratory flow; $\mathrm{CO}_{2}$, carbon dioxide; $\mathrm{PaO}_{2}$, oxygen partial pressure; $\mathrm{PaO}_{2} / \mathrm{FiO}_{2}$, derived arterial oxygen tension to inspiratory oxygen fraction ratio; $\mathrm{FEF50}$, forced expiration flow at 50\% of vital capacity. 
hypertonic treatment phase compared with the isotonic control phase was observed. Significant differences were found for SGRQ global score and in domains of symptoms and impacts $(p<0.05)$, but not for domain activity. A retrospective analysis found a lower use of antibiotics $(p<0.05)$ and number of exacerbations $(p<0.05)$ in the active phases of the study compared to the period prior to the study [37]. An RCT compared the use of HS at $6 \%$ with the use of IS at $0.9 \%$ twice per day for a period of 12 months. A daily diary was used to record patient adherence, changes in medical therapy, and symptoms (differences in sputum color or volume, hemoptysis, coughing, dyspnea, lethargy, fever or nasal secretions). There was no statistically significant difference at 3, 6, and 12 months between the two groups [38].

\section{Physical exercise}

Some studies have investigated the role and effectiveness of specific muscle training programs and/or respiratory muscle training in bronchiectasis patients (Table 5).

Newall examined the effects of a non-specific training program, with and without the combination of IMT, on exercise tolerance and QoL versus control group only involved in educational meetings. A significant increase in ISWT in both sham (PR-SHAM) and intervention (PR-IMT) groups (96.7 $\mathrm{m}$ and $124.5 \mathrm{~m}$ respectively) compared to baseline was observed after 8 weeks without significant differences between the two groups. Significant improvement in the strength of respiratory muscles was observed, with an increase in maximal inspiratory pressure (MIP) in both groups who performed training, without significant differences between the two groups $(p=0.22)$. There was no improvement in the peak maximal oxygen uptake $\left(\mathrm{VO}_{2} \max \right)$ in any of the three groups. At three months follow-up evaluation, improvement in exercise capacity was maintained only in the PR-IMT group compared to PR-SHAM group ( $\mathrm{p}=0.01$ ). Also, SGRQ significantly improved in the PR-IMT group compared to the control group $(\mathrm{p}=0.05)$. Conversely, in the PR-SHAM group there was no significant improvement in QoL despite the improvement in exercise capacity. Finally, no significant changes in the sputum volume were observed in any of the participants [39].

To confirm that the same chest rehabilitation programs used in COPD patients are effective also in patients with bronchiectasis, Ong [40] retrospectively compared the effects of the same outpatient retraining program performed in patients with bronchiectasis and in patients with COPD. At the end of an eight-week rehabilitation program, a significant improvement in the 6MWT (53-meter average increase) and in the CRQ (average change of 14.0 units) was observed in the bronchiectasis group. This positive effect was also significantly higher than the baseline at one year (20.5-meter average increase for 6MWT increase and 12.1 points at CRQ) and did not differ from those found in the COPD patients' group. Another retrospective study [41] showed significant improvement in vital capacity (VC) and a significant reduction in RV in 41 patients with bronchiectasis ( 7 with Cystic Fibrosis) after a 12-week training program, although the increase in the 6MWT did not show significant variations. The authors demonstrated that physical exercise was not contraindicated, and developed functional benefits,

Table 3. Physiological studies about effects of manual or mechanical oscillation.

\begin{tabular}{|c|c|c|c|c|c|c|}
\hline Reference & $\begin{array}{l}\text { No. of patients } \\
\left(F E V_{1}\right)\end{array}$ & Study design & Treatment & & Outcomes & $\begin{array}{l}\text { Significant } \\
\text { result }\end{array}$ \\
\hline Valente 2004 [28] & $8(63 \%)$ & $\begin{array}{l}\text { Crossover } 3 \text { days } \\
\text { (no wash out) }\end{array}$ & $\begin{array}{ll}1 \text { time per day - lasting } 40 \mathrm{~m} \\
\text { Flutterns } & \text { Sharm } \\
& \text { flutter } \\
& \text { PEP set at } 6 \\
& \mathrm{Cm} \mathrm{H}_{2} \mathrm{O}\end{array}$ & $\begin{array}{l}\text { nin } \\
\end{array}$ & $\begin{array}{l}\text { Sputum viscosity } \\
\text { and stickiness } \\
\text { with oscillations }\end{array}$ & $\begin{array}{l}\text { No changes in } \\
\text { sputum rheology }\end{array}$ \\
\hline Tambascio 2011 [29] & $18(60 \%)$ & $\begin{array}{l}\text { Crossover } \\
4 \text { weeks(1 week } \\
\text { wash out) }\end{array}$ & $\begin{array}{l}1 \text { time per day - lasting } 30 \mathrm{~m} \\
\text { Patient in sitting position } \\
\text { Therapist overlook } \\
\text { Flutterns }\end{array}$ & Sham flutterns & $\begin{array}{l}\text { Sputum viscosity } \\
\text { and stickiness }\end{array}$ & $\begin{array}{l}\downarrow \text { Sputum stickiness } \\
\text { after flutter }\end{array}$ \\
\hline Figueiredo 2012 [30] & $8(65 \%)$ & $\begin{array}{l}\text { Crossover } 2 \text { days } \\
\text { (1 week wash } \\
\text { out) }\end{array}$ & $\begin{array}{l}1 \text { time per day - lasting } 15 \mathrm{~m} \\
\text { Flutter } \\
\text { Patient in sitting position, } \\
\text { inspirations to TLC and } \\
\text { relaxed exhalation }\end{array}$ & $\begin{array}{l}\text { ain }+5 \text { min cough } \\
\text { Sham flutter } \\
\text { Patient in sitting } \\
\text { position, inspirations } \\
\text { to TLC and relaxed } \\
\text { exhalation }\end{array}$ & $\begin{array}{l}\text { Respiratory } \\
\text { mechanics with } \\
\text { oscillometer }\end{array}$ & $\begin{array}{l}\downarrow \text { Airway resistance } \\
\text { after flutter }\end{array}$ \\
\hline Ramos 2015 [31] & 22 (n.s.\%) & $\begin{array}{l}\text { Cross over } \\
4 \text { days(no wash } \\
\text { out) }\end{array}$ & 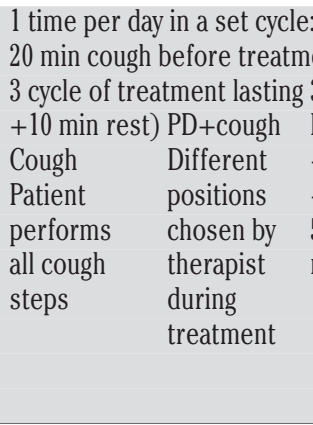 & $\begin{array}{ll} & \\
\text { ent }+10 \text { min rest+ } \\
30 \text { min }(20 \text { min } \\
\text { PD } & \text { PD + HUFF } \\
+ \text { +cough } & 2 \text { forced } \\
+ \text { clapping } & \text { expirations } \\
500 \text { beats/ } & \text { with open } \\
\text { min } & \text { glottis }\end{array}$ & $\begin{array}{l}\text { Sputum typesetting, } \\
\text { viscosity and } \\
\text { elasticity }\end{array}$ & $\begin{array}{l}\uparrow \% \text { dry and wet } \\
\text { sputum after } 60 \\
\text { min of PD+ } \\
\text { clapping } \\
\uparrow \% \text { dry sputum } \\
\text { after } 90 \text { min of } \\
\text { PD+HUFF } \\
\uparrow \% \text { wet sputum } \\
\text { after } 60 \text { min of } \\
\text { PD+HUFF }\end{array}$ \\
\hline
\end{tabular}

$\uparrow$, increase, improvement; $\downarrow$, only decrease, no negative meaning or worsening; ns, not specified; PEP, positive expiratory pressure; HUFF, forced expiration with open glottis; PD, postural drainage; ELTGOL, expiration lente totale glotte ouverte en decubitus lateral; $\mathrm{FEV}_{1}$, forced expiration volume at first second; TLC, total lung capacity . 
also in severely obstructed patients (mean $\mathrm{FEV}_{1} 44 \%$ of predicted). They suggested a lack of improvement in the 6MWT due to the fact that enrolled subjects had a high baseline exercise tolerance (mean distance covered $425 \mathrm{~m}$ ). Oher comments from the same study were that the design of training programs for bronchiectasis patients should differ from those for patients with COPD in terms of intensity, frequency and duration of sessions.

A high-intensity training program (workload achieving a heart rate of $70-80 \%$ of the maximum reached at $6 \mathrm{MWT}$ and a Borg dyspnea score of 3-5) was implemented in another retrospective study. A significant improvement in the 6MWT, QoL and dyspnea reduction [42] was observed.

Two further studies have compared training programs in addition to ACTs $[43,44]$. In the study published by Mandal et al. [43], 30 patients with clinical stability and purulent or mucopurulent expectoration who performed regular airway clearance sessions were randomized into two groups: a control group performing bronchial airway clearance twice a day, and a treatment group, which added a three weekly training session. At the end of the study, there was a significant improvement in the treatment group: ISWT

Table 4. Studies evaluating the use of adjuncts to physiotherapy (humidification or saline nebulization).

\begin{tabular}{|c|c|c|c|c|c|}
\hline Reference & $\begin{array}{l}\text { No. of patients } \\
\left(\mathrm{FEV}_{1}\right)\end{array}$ & Study design & Treatment & Outcomes & $\begin{array}{l}\text { Significant } \\
\text { result }\end{array}$ \\
\hline Conway 1992 [32] & $\begin{array}{l}7 \\
\text { (46\% on average, } \\
\text { broad range) }\end{array}$ & $\begin{array}{l}\text { Crossover } \\
2 \text { days } \\
\text { (1 week wash } \\
\text { out) }\end{array}$ & 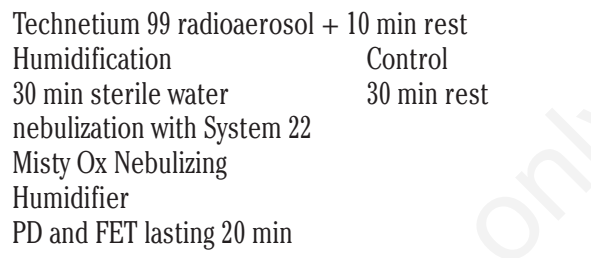 & $\begin{array}{l}\text { Radiolabel } \\
\text { clearance, } \mathrm{FEV}_{1} \text {, } \\
\text { sputum weight } \\
\text { after humidification }\end{array}$ & $\begin{array}{l}\uparrow \text { Radiolabel } \\
\text { clearance and } \\
\text { sputum weight }\end{array}$ \\
\hline Hasan 2008 [33] & $14(51 \%)$ & $\begin{array}{l}\text { Prospective } \\
\text { observational } \\
7 \text { days }\end{array}$ & $\begin{array}{l}\text { Domiciliary humidification } 3 \text { hours per day with } \\
\text { MR } 880 \text { humidifier with nasal flow system } 20-25 \mathrm{~L} / \mathrm{min} \\
\text { Temperature } 37^{\circ} \mathrm{C}\end{array}$ & $\begin{array}{l}\text { Radiolabel } \\
\text { clearance, } \\
\text { FEV1, FVC, } \\
\text { Penetration index, } \\
\text { Alveolar deposition, } \\
\text { AUC }\end{array}$ & $\begin{array}{l}\uparrow \text { Radiolabel } \\
\text { clearance and AUC } \\
\text { with humidification }\end{array}$ \\
\hline Rea 2010 [34] & $\begin{array}{l}108 \text { mixed group } \\
\text { NCFB and COPD } \\
(60 \%)\end{array}$ & RCT 12 months & $\begin{array}{ll}\text { Humidification } & \text { Control } \\
2 \text { hours per day at least with } & \text { Usual care } \\
\text { MR880 humidifier with optiflow } & \\
\text { system } & \end{array}$ & $\begin{array}{l}\mathrm{FEV}_{1}, \mathrm{FVC} \\
\text { Exacerbation rate, } \\
\text { hospitalization rate, } \\
\text { SGRQ, } \\
\text { 6MWT, } \\
\text { inflammatory } \\
\text { markers }\end{array}$ & $\begin{array}{l}\uparrow \mathrm{FEV}_{1}, \mathrm{FVC} \text { with } \\
\text { humidification } \\
\downarrow \mathrm{SGRQ} \text { and } \\
\text { exacerbation rate } \\
\text { with humidification }\end{array}$ \\
\hline Kellett 2005 [36] & $\begin{array}{l}24(\mathrm{~ns}) \\
\text { Sputum }<10 \mathrm{ml} \\
\text { per day }\end{array}$ & $\begin{array}{l}\text { Crossover } \\
4 \text { weeks } \\
\text { (1 week wash } \\
\text { out) }\end{array}$ & 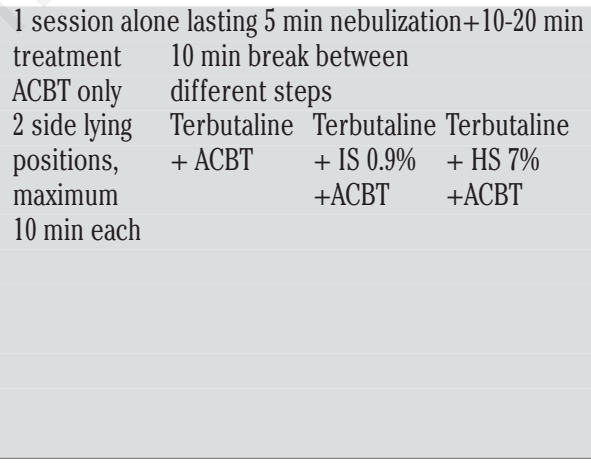 & $\begin{array}{l}\text { Spirometric } \\
\text { parameters, } \\
\text { sputum weight, } \\
\text { sputum viscosity, } \\
\text { ease of } \\
\text { expectoration (VAS) }\end{array}$ & $\begin{array}{l}\uparrow \text { sputum weight, } \\
\text { sputum viscosity } \\
\text { and ease of } \\
\text { expectoration } \\
\text { with HS e IS } \\
\text { compared to ACBT } \\
\text { only } \\
\text { 个sputum weight, } \\
\text { sputum viscosity } \\
\text { and ease of } \\
\text { expectoration with } \\
\text { HS compared to IS }\end{array}$ \\
\hline Kellett 2011 [37] & $32(66,4 \%)$ & $\begin{array}{l}\text { Crossover } \\
8 \text { months } \\
\text { (1 month wash } \\
\text { out) }\end{array}$ & $\begin{array}{l}5 \text { times per week lasting } 30 \text { min per day } \\
\mathrm{HS} \\
4 \mathrm{ml} 7 \%\end{array}$ & $\begin{array}{l}\text { Spirometric } \\
\text { parameters, } \\
\text { SGRQ, antibiotic } \\
\text { usage, exacerbation } \\
\text { rate, sputum } \\
\text { viscosity, ease of } \\
\text { expectoration (VAS) }\end{array}$ & $\begin{array}{l}\uparrow \text { FEV1, FVC after } \\
\text { HS } \\
\downarrow \text { SGRQ (except } \\
\text { activity domain), } \\
\text { exacerbation rate } \\
\text { and antibiotic } \\
\text { usage after HS }\end{array}$ \\
\hline Nicholson 2012 [38] & $48(82.6 \%)$ & $\begin{array}{l}\text { RCT } \\
12 \text { months }\end{array}$ & $\begin{array}{l}2 \text { times per day } \\
\text { Daily diary } \\
100 \text { g sulbutamol with spacer } \\
\text { Stop usual ACT } \\
\text { HS5 mL 6\% }\end{array}$ & $\begin{array}{l}\text { Spirometric } \\
\text { parameters, SGRQ, } \\
\text { LCQ, exacerbation } \\
\text { rate, sputum } \\
\text { typesetting }\end{array}$ & $\begin{array}{l}\text { Good acceptability } \\
\text { of sessions }\end{array}$ \\
\hline
\end{tabular}

$\uparrow$, increase, improvement; $\downarrow$, only decrease, no negative meaning or worsening; ns, not specified; RTC, randomised controlled trial; FEV1, forced expiration volume at first second; FVC, forced vital capacity; IS, Isotonic Saline solution; HS, Hypertonic Saline solution; PD, postural drainage; FET, forced expiration technique; ACBT, active cycle of breathing technique; VAS, visual analogic scale; AUC, area under tracheobronchial retention curve; SGRQ, Saint George respiratory questionnaire; LCQ, Leicester cough questionnaire; COPD, chronic obstructive pulmonary disease; NCFB, non-fibrosis cystic bronchiectasis; 6MWT, 6 minutes walking test. 
and endurance walk test (EWT) increased $56.7 \mathrm{~m}(\mathrm{p}=0.03)$ and $193.3 \mathrm{~m}(\mathrm{p}=0.01)$ respectively. Furthermore, QoL questionnaires were improved: LCQ increased by 2.6 units $(\mathrm{p}<0.001)$ and SGRQ by 8 units $(p<0.001)$ in the training group. No improvement was observed in the control group that only performed bronchial airway clearance sessions with Acapella. Even at 20 weeks, 3 months after

Table 5. Studies evaluating pulmonary rehabilitation programs (aerobic exercise training, lower and upper limb strength training, inspiratory muscle training).

\begin{tabular}{|c|c|c|c|c|c|}
\hline Reference & $\begin{array}{l}\text { No. of patients } \\
\left(\mathrm{FEV}_{1}\right)\end{array}$ & Study design & Treatment & Outcomes & $\begin{array}{l}\text { Significant } \\
\text { result }\end{array}$ \\
\hline Newall 2005 [39] & $32(62 \%)$ & $\begin{array}{l}\text { RCT } \\
8 \text { weeks } \\
\text { Follow up } \\
3 \text { months }\end{array}$ & $\begin{array}{ll}\text { Educational program } & \text { Control } \\
2 \text { times per week assisted } & \\
\text { sessions lasting } 15 \text { min cycle } & \\
\text { ergometer }+15 \text { min treadmill } \\
+15 \text { min stairs (training set at } \\
\text { 80\% maximum heart rate) } \\
\text { + } 1 \text { time per week home } \\
\text { session } 45 \text { min walking } \\
\text { PR+Sham } & \text { PR+IMT } \\
\text { device15 min } & 15 \text { min } 2 \text { times } \\
2 \text { times per } & \text { per week } \\
\text { week } & \text { Threshold } \\
\text { Threshold } & \text { device set at a } \\
\text { device set at } & 30 \% \text { MIP } \\
7 \text { cm } \mathrm{H}_{2} \mathrm{O} & \text { Progression } \\
& \text { set at }+5 \% \\
& \text { every week up } \\
& \text { to } 60 \% \text { MIP }\end{array}$ & $\begin{array}{l}\text { MIP, MEP, } \\
\text { VO }_{2} \text { peak } \\
\text { Endurance } \\
\text { exercise test } \\
\text { (treadmill), } \\
\text { ISWT, } \\
\text { SGRQ, } \\
\text { Sputum volume }\end{array}$ & $\begin{array}{l}\uparrow M I P \text {, endurance } \\
\text { test, ISWT in PR } \\
\text { groups compared } \\
\text { to control } \\
\downarrow \text { SGRQ after } \\
\text { PR+IMT } \\
\text { After } 3 \text { months } \\
\text { improvement in } \\
\text { endurance exercise } \\
\text { capacity was } \\
\text { maintained only in } \\
\text { the PR+IMT group }\end{array}$ \\
\hline Ong 2011 [40] & $\begin{array}{l}111(60 \%) \\
81 \text { out of } 111 \\
\text { were NCFB }\end{array}$ & $\begin{array}{l}\text { Retrospective } \\
8 \text { weeks } \\
\text { Follow up } \\
12 \text { months }\end{array}$ & $\begin{array}{l}4 \text { times per week ( } 2 \text { assisted sessions, } 2 \text { at home) } \\
\text { lasting 60-90 min: } \\
15 \text { min cycle ergometer (intensity according Borg) } \\
+15 \text { min treadmill ( } 70 \% \text { 6MWT, progression } \\
\text { according Borg) + } 15 \text { min strengthening/functional } \\
\text { exercises } \\
\text { NCFB }\end{array}$ & $\begin{array}{l}\text { 6MWT } \\
\text { CRQ }\end{array}$ & $\begin{array}{l}\uparrow 6 \mathrm{MWT} \text { and } \mathrm{CRQ} \text { in } \\
\text { both groups } \\
\text { After } 1 \text { year, } \\
\text { improvements } \\
\text { were maintained }\end{array}$ \\
\hline Van Zeller 2012 [41] & $\begin{array}{l}41(44.6 \%) \\
7 \text { out of } 41 \text { were } \mathrm{CF}\end{array}$ & $\begin{array}{l}\text { Retrospective } \\
12 \text { weeks }\end{array}$ & $\begin{array}{l}3 \text { times per week lasting } 30 \text { min: } \\
\text { cycle ergometer (target load 60\% maximum work } \\
\text { rate or tolerance) + upper limbs and quadriceps } \\
\text { training }\end{array}$ & $\begin{array}{l}\text { Spirometric } \\
\text { parameters, } \\
\text { blood gas analysis, } \\
\text { 6MWD }\end{array}$ & $\begin{array}{l}\downarrow R V \text { and } \uparrow F E V 1 \text { in } \\
\text { patients with } \\
\mathrm{FEV}_{1}<50 \% \\
\downarrow R V \text { and } \uparrow F V C \text { in } \\
\text { patients with } \\
\text { idiopathic etiology }\end{array}$ \\
\hline Zanini 2015 [42] & $108(76 \%)$ & $\begin{array}{l}\text { Retrospective } \\
3 \text { weeks }\end{array}$ & $\begin{array}{l}5 \text { times per week lasting 2-3 hours: } \\
30-40 \text { min cycle ergometer or treadmill (initial load } \\
60-70 \% \text { maximum heart rate in 6MWT) + upper limb } \\
\text { training+ educational activitiesAirway clearance } \\
\text { techniques, positioning and IMT if necessary }\end{array}$ & $\begin{array}{l}\text { Spirometric } \\
\text { parameters, } \\
\text { DBI/TDI, 6MWT, } \\
\text { EQ-VAS }\end{array}$ & $\begin{array}{l}\uparrow T D I \\
\uparrow 6 \mathrm{MWT} \text { especially } \\
\text { in male patients } \\
\text { with low FEVl and } \\
\text { exacerbation rate } \\
>2 / y e a r \\
\uparrow E Q-V A S \text { especially } \\
\text { in male patients } \\
\text { with low } \mathrm{FEV}_{1}\end{array}$ \\
\hline Mandal 2012 [43] & $27(74 \%)$ & $\begin{array}{l}\text { RCT8 weeks } \\
3 \text { months } \\
\text { follow up }\end{array}$ & 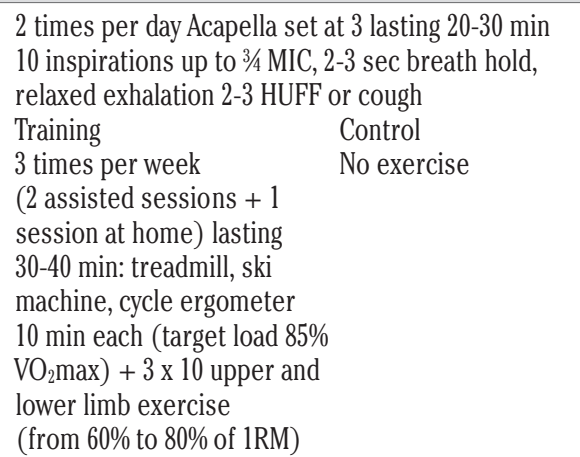 & $\begin{array}{l}\text { Spirometric } \\
\text { parameters, } \\
\text { ISWT, EWT, LCQ, } \\
\text { SGRQ, MIP, MEP, } \\
\text { inflammatory } \\
\text { markers } \\
\text { After } 3 \text { months, } \\
\text { improvements } \\
\text { were maintained }\end{array}$ & $\begin{array}{l}\uparrow I S W T, \text { EWT, LCQ } \\
\text { in training group } \\
\downarrow \text { SGRQ in training } \\
\text { group }\end{array}$ \\
\hline
\end{tabular}


the end of training, the improvement was only present in the intervention group, with an increase in the ISWT (80mt, $\mathrm{p}=0.04)$, EWT (247.5mt, $\mathrm{p}=0.003)$, LCQ score (4.4 units, $\mathrm{p}<0.001)$, and SGRQ score (4 units, $\mathrm{p}<0.001$ ).

The second study [44] which compared the effects of a training program in addition to usual ACT, evaluated the short and long term effects on the capacity to sustain exercise, QoL, and the incidence of exacerbations. The study involved 85 clinically stable bronchiectasis patients with dyspnea $\geq 1$ according to the modified Medical Research Council scale (mMRC) and a history of two or more exacerbations per year which required antibiotic therapy in the two years previous the study. At the end of the 8-week treatment, the improvement in the distance walked on ISWT (average difference of $62 \mathrm{~m}$ ) and 6MWT (mean difference of $41 \mathrm{~m}$ ) was higher in the treatment group than in the control group. This effect was lost at 6 and 12-month follow-up. In the exercise group, there

Table 5. Continued from previous page.

\begin{tabular}{|c|c|c|c|c|c|}
\hline Reference & $\begin{array}{l}\text { No. of patients } \\
\left(F E V_{1}\right)\end{array}$ & Study design & Treatment & Outcomes & $\begin{array}{l}\text { Significant } \\
\text { result }\end{array}$ \\
\hline Lee 2014 [44] & $\begin{array}{l}85(73 \%) \\
\text { follow up }\end{array}$ & $\begin{array}{l}\text { RCT8 weeks } \\
6 \text { and } 12 \text { months }\end{array}$ & $\begin{array}{l}\text { Usual ACT } \\
\text { Symptoms diary } \\
\text { Training } \\
5 \text { times per week } \\
\text { (2 assisted sessions } \\
+3 \text { sessions at home) } \\
\text { lasting } 30 \text { min of cycle } \\
\text { ergometer (initial load } \\
60 \% \text { maximum work rate) } \\
\text { or treadmill (initial load } \\
75 \% \text { of ISWT) + upper and } \\
\text { lower limb strength } \\
\text { training using free weights }\end{array}$ & $\begin{array}{l}\text { ISWT } \\
\text { CRQ } \\
6 \mathrm{MWT} \\
\text { LCQ } \\
\text { HADS } \\
\text { Control } \\
30 \text { min moderate } \\
\text { daily activity }\end{array}$ & $\begin{array}{l}\uparrow \text { ISWT, } 6 \mathrm{MWT} \text { in } \\
\text { training group } \\
\text { After } 6 \text { and } 12 \\
\text { months } \\
\text { improvements } \\
\text { were NOT } \\
\text { maintained } \\
\downarrow \text { exacerbation } \\
\text { rate after } 12 \\
\text { months in training }\end{array}$ \\
\hline Liaw 2011 [45] & $26(58 \%)$ & RCT8 weeks & $\begin{array}{ll}\text { Monthly phone call control } & \text { Control } \\
\text { Training } 5 \text { times per week } & \text { No training } \\
\text { lasting } 30 \text { min IMT threshold } & \\
\text { device (set } 30 \% \mathrm{MIP}, & \\
\text { progression }+2 \mathrm{cmH}_{2} \mathrm{O} \\
\text { every week) }\end{array}$ & $\begin{array}{l}\text { Spirometric } \\
\text { parameters, } \\
\mathrm{O}_{2} \text { saturation, } \\
\text { Borg scale, 6MWD, } \\
\text { 6Mwork, MIP, MEP, } \\
\text { SGRQ }\end{array}$ & $\begin{array}{l}\uparrow M I P, \text { MEP in } \\
\text { training group }\end{array}$ \\
\hline
\end{tabular}

$\uparrow$, increase, improvement; $\downarrow$, only decrease, no negative meaning or worsening; ns, not specified; RTC, randomised controlled trial; PR, pulmonary rehabilitation; IMT, inspiratory muscle training; MIP, maximum inspiratory pressure; MEP, maximum expiratory pressure; FEV $\mathrm{F}_{1}$, forced expiration volume at first second; FVC, forced vital capacity; RV, residual volume; VAS, visual analogic scale; SGRQ, Saint George respiratory questionnaire; LCO, Leicester cough questionnaire; ISWT, incremental shuttle walking test; EWT, endurance walking test; CRO, chronic respiratory disease questionnaire; TDI, transitional dyspnea index; BDI, baseline dyspne index: EQ-VAS, EuroQoL visual analogic scale; COPD, chronic obstructive pulmonary disease; $\mathrm{CF}$, cystic fibrosis; NCFB, non-fibrosis cystic bronchiectasis; 6 MWT, 6 minutes walking test; 6 MWD, 6-minute walking distance; 6 Mwork, 6-minute walking work; 1RM, 1 repetition maximum; ACT, airway clearance therapy; MIC, maximal inspiratory capacity; HUFF, forced expiration with open glottis; HADS, hospital anxiety and depression scale.

Table 6. Main result for outcome.

\begin{tabular}{|c|c|c|}
\hline Outcome & Main results & Notes \\
\hline $\begin{array}{l}\text { Number of exacerbations/ } \\
\text { hospital admission }\end{array}$ & $\begin{array}{l}\text { ACTs may decrease number of exacerbations } \\
\text { High Flow systems and saline nebulization (HS better than IS) } \\
\text { may decrease number of exacerbations } \\
\text { PR may decrease number of exacerbations }\end{array}$ & Very few studies have considered this outcome \\
\hline Health related quality of life & $\begin{array}{l}\text { ACTs may improve QoL, dyspnea and fatigue } \\
\text { High flow system and saline nebulization (HS better than IS) } \\
\text { may improve QoL } \\
\text { PR may reduce dyspnea and fatigue and enhance ability to sustain } \\
\text { exercise. IMT alone can't improve QoL but can help to extend } \\
\text { benefits of PR }\end{array}$ & $\begin{array}{l}\text { Few studies have considered this correlation, } \\
\text { conflicting data } \\
\text { Conflicting data } \\
\text { Consensus in short term benefits, few items } \\
\text { about long term benefits }\end{array}$ \\
\hline Symptoms & $\begin{array}{l}\text { Sputum volume increases with ACTs, no evidence among different } \\
\text { techniques } \\
\text { Sputum volume increase with humidification and saline nebulization }\end{array}$ & $\begin{array}{l}\text { Many studies report sputum volume, but it is a } \\
\text { poor outcome, many bias because of different } \\
\text { collection method }\end{array}$ \\
\hline Respiratory function & $\begin{array}{l}\text { ACTs, humidification and saline nebulization may improve same } \\
\text { selected parameters } \\
\text { PR may improve respiratory function in selected patients }\end{array}$ & $\mathrm{FEV}_{1}$ is not always statistically relevant \\
\hline $\begin{array}{l}\text { Safety and tolerability of } \\
\text { treatments }\end{array}$ & $\begin{array}{l}\text { No adverse effects were described } \\
\text { All treatments were well-tolerated }\end{array}$ & \\
\hline
\end{tabular}

ACTs, airway clearance technique; HS, hypertonic saline solution; IS, isotonic saline solution; PR, pulmonary rehabilitation; FEVl, forced expiration volume at first second; IS, isotonic saline solution; HS, hypertonic saline solution; QoL, quality of life; IMT, inspiratory muscle training. 
was also a reduction in dyspnea $(\mathrm{p}=0.009)$ and muscle fatigue $(\mathrm{p}=0.01$ ), but no significant improvement in CRQ, LCQ and psychological conditions [hospital anxiety depression scale (HADS)]. Among the long-term results, a significant reduction in the number of exacerbations was observed at 12 months in the treatment group compared to the control group $(\mathrm{p}=0.012)$.

A single study, Liaw et al. [45] evaluated the feasibility and effectiveness of a respiratory muscle training program. At the end of the study, only a significant MIP improvement (mean -25.3 versus $-16.4 \mathrm{cmH}_{2} \mathrm{O}, \mathrm{p}=0.005$ ) and maximal expiration pressure (MEP) $\left(\right.$ mean +30.8 versus $\left.+20.8 \mathrm{cmH}_{2} \mathrm{O} \mathrm{p}=0.038\right)$ were observed in the treatment group.

\section{Discussion}

\section{Bronchial airway clearance}

ACTs are physiotherapy interventions designed to facilitate the removal of tracheo-bronchial and lung secretions. In clinical practice, a large number of single or combined techniques based on different intervention strategies are used: positioning, pulmonary volume and expiratory flow changes, application of positive expiratory pressure, vibration, airway oscillations and chest wall oscillations $[46,47]$

Although some guidelines recommend the use of chest physiotherapy [7,9] and there is consensus in the literature over the associated improvements in symptoms and QoL [48-50], its effectiveness has not been clearly demonstrated in patients with bronchiectasis.

The difficulty in determining its efficacy is related to disease heterogeneity, linked to individual variability in daily sputum volume, the magnitude of ventilatory limitation and degree of obstruction, and the severity of respiratory symptoms $[1,7,8,46]$.

The majority of the published studies show several methodological limitations that can affect their results. Most studies had a small sample size and a crossover design [12,16-18,22,2730]. Only three studies compared an airway clearance technique with a placebo (sham therapy) $[19,29,30]$ and only three studies had a control group that did not perform any treatment, other than medical therapy $[17,18,26]$.

One of the mayor difficulties in evaluating the effectiveness of ACTs lies in selecting appropriate outcome measures that accurately reflect therapeutic effects, such as improved mucus transport, or secondary effects of mucus removal as frequency and the duration of exacerbations, hospitalization days, changes in respiratory function and QoL. Secretion removal is often evaluated by measuring the volume of sputum produced. This evaluation may be highly influenced by factors as inhibition of the patient expectoration, secretions swallowing, etc. In the studies we have analyzed, the sputum was significantly increased in the following treatments: ACBT + PD compared to Flutter [14] Flutter versus sham-Flutter [29], Acapella compared to no treatment [17] or IMT [22], ELTGOL compared to placebo [19], and HFCWO compared to conventional or no treatment [26]. Spirometric parameters are frequently used as short-term outcome, although there are some limitations in using them. The presence of secretions may have different effects depending on the level of obstruction. Secretions may worsen obstruction by reducing the expiratory flow in the small airways, whereas complete airway obstruction can lead to a reduction in lung volumes. $\mathrm{FEV}_{1}$ was seldom significantly modified [12,23,26] despite all studies having considered spirometric measures. The study of Guimarães et al. suggested a correlation between sputum quantity and a static volume improvement [18]. Nevertheless, this data was applicable only to the bronchiectasis phenotype with detectable dynamic hyperinflation. It is therefore difficult to find changes in these parameters if a small number of patients are analyzed. Finally, the effect of airways clearance programs on QoL has been analyzed in two studies [17,19] which demonstrated an improvement in cough, an improvement in the psychological /social impact, an improvement of exercise tolerance and a reduction of exacerbation rate. The distinguishing feature of the study performed by Munoz [19] relative to other randomized clinical trials was the longer duration of intervention.

This should open a debate as to what is the most clinically relevant endpoint to measure the effectiveness of airway clearance (Table 6).

\section{Interventions aiding airway clearance}

Conway and Hasani $[32,33]$ observed an improvement in mucociliary clearance after using sterile water nebulization and warm humidification with a high flow system. Regarding the long-term use (12 months), a single study [34] reported a statistically significant improvement on the exacerbation rate, and lung function at 6 to 12 months. There was a decrease in antibiotic therapy. Also an improvement of QoL measured by SGRQ in all domains, except for activity was observed. The results of this study, however, have to be considered with caution, since the patients population included 73 COPD and 45 bronchiectasis subjects without separated analysis performed.

Concerning saline nebulization, we found a statistically significant improvement in sputum volume, in ease and viscosity of sputum clearing with HS (7\%) compared to IS [36]. Moreover, with HS (7\%) improved $\mathrm{FEV}_{1}$ and FVC, QoL (except for domain activity), and lower use of antibiotic therapy and number of exacerbations were observed [37].

Very different results, however, were reported by Nicolson [38] who demonstrated no significant improvement in QoL, respiratory function, number of exacerbations or changes of sputum colonization by comparing the use of IS and HS at $6 \%$ for 12 months with two nebulizations per day.

\section{Physical exercise}

In bronchiectasis as in other respiratory conditions, especially in the most advanced stages, the combination of bronchial obstruction and pulmonary hyperinflation may worsen dyspnea and result in reduced tolerance to physical exercise and QoL $[5,51,52]$.

All studies in which physical exercise training was performed have clearly demonstrated short-term improvements in the ability to sustain exercise, with reduced dyspnea and fatigue [39-44,53]. This effect was comparable to those reported in COPD patients treated with similar programs [7].

Studies showing also long-term results have observed different results. Improvement in the ability to sustain physical exercise was maintained at the 3 month-follow-up in the studies of Mandal [43] and Newal 1[39], and at one year follow-up in Ong's study [40]. However, this effect was not maintained after 6 and 12 months in Lee's study [44].

Long term results regarding QoL are also different: in the 
Newall's study [39] the improvement in QoL measured with SGRQ at the end of treatment persisted at 3 months; otherwise, QoL in Ong's study [40] (measured with the CRQ) and Mandal's study [43] (measured with LCQ and SGRQ) showed improvement at the end of the program, and the benefits were maintained at 20 weeks and 12 months, respectively. In the study performed by Lee [44], even if physical exercise reduced dyspnea and fatigue, no changes were observed in LCQ and HADS. These findings suggest that this type of intervention should include maintenance programs useful in modifying patient lifestyles for long-term benefits. Moreover, an important emerging issue in the long-term follow-up, as demonstrated by Lee's study [44], is a lower incidence of exacerbations in subjects participating in a full pulmonary rehabilitation program compared to the group who only performed airway clearance.

The training of respiratory muscles in patients with bronchiectasis is feasible and seems to improve the strength of respiratory muscles as already demonstrated in COPD subjects. Nevertheless, if it is performed without the addition of a physical exercise program, is incapable to improve short term respiratory function and QoL [44]. It has been shown that a respiratory muscle training associated with lower limb muscle training can affect the distance maintenance obtained with a physical exercise program and improve the QoL [39].

Exercise may play a role in favoring mucus expectoration [54], but such observations were not confirmed in the study of Newall [39]. The author found no significant changes in sputum volume in subjects who performed high intensity exercise, nor in the group who added lower limb muscle training to a respiratory muscles training program. Unfortunately, other studies comparing bronchial airway clearance programs with the addition of peripheral muscle training did not insert sputum amount between the outcome measures. Therefore, this observation cannot be confirmed nor denied.

It is unclear whether individual bronchial airway clearance programs may play a role in improving the ability to enhance physical exercise, and reduce dyspnea and fatigue [46,48]. Some studies did not find any improvement in dyspnea scales (VAS or Borg) after an airway clearance session $[12,13,16]$, whereas other studies have showed improvements in ISWT [17], mMRC [20,26] and breathlessness, cough and sputum scale (BCSS) [26]. The paucity of information is obviously due to the fact that the ability to perform physical exercise is not a primary outcome in airway clearance programs.

So far, studies on training programs in patients with bronchiectasis are few and far from homogeneous in design and management. Patients have not been selected in relation to clinical severity clusters, type, intensity, frequency. Furthermore, the duration of individual sessions has been variable and outcomes not always comparable. New studies are therefore desirable to provide clearer guidance on the essential components and the most effective ways of conducting specific training programs for patients with bronchiectasis.

\section{Limitations}

This review has some limitations. First, quality and weigh of the various studies have not been evaluated. Second, the heterogeneity across the selected studies may have affected the results of the review. However, the high number of records may give further hints on the effects of the various interventions.

\section{Conclusions}

Bronchiectasis represent the result of confluent factors involving infectious, genetic, autoimmune, evolutive and allergic components. Etiology, clinical manifestations and prognosis may be very heterogeneous [8]. This scenario makes it difficult to individualize the best outcome in terms of physiologic and or clinical benefit for non-cystic fibrosis bronchiectasis patients.

ACTs seem effective in increasing sputum volume although no benefit in QoL or exacerbation rate have been shown. There were no differences in effectiveness between several techniques used. From our point of view, ACTs should also be accompanied by global rehabilitation interventions involving educational aspects in the management of the disease. Proper management of medical therapy and early recognition of exacerbations, linked to endurance training programs should be included. PR has been associated with short term benefits in exercise capacity, dyspnea and fatigue. Exercise training might improve QoL and exacerbation rate, but long-term data are not available. No adverse effects were described. All treatments were well-tolerated.

As emphasized by the European Multicentre Bronchiectasis Audit and Research Collaboration (EMBARC), physiotherapy and respiratory rehabilitation are the major topics of research in the field of bronchiectasis. Further studies are needed to optimize compliance, access to bronchial airway clearance and physical exercise training [55].

In particular, future studies should include significant clinical outcomes as the number of exacerbations, access to medical assistance, and improvements in QoL. Patients selection should also be oriented towards a better stratification and should take associated comorbidities into account.

\section{References}

1. McShane PJ, Naureckas ET, Tino G, Strek ME. Non-cystic fibrosis bronchiectasis. Am J Respir Crit Care Med 2013; 188:647-56.

2. King PT. The pathophysiology of bronchiectasis. Int J Chron Obstruct Pulmon Dis 2009;4:411-9.

3. Ten Hacken NH, Kerstjens HA. Bronchiectasis. BMJ Clin evid 2011;1507.

4. Martinez-Garcia MA, Perpina-Tordera M, Roman-Sanchez P, Soler-Cataluňa JJ. Quality-of-life determinants in patients with clinically stable bronchiectasis. Chest 2005; 128:739-45.

5. Koulouris NG, Retsou S, Kosmas E, et al. Tidal expiratory flow limitation, dyspnoea and exercise capacity in patients with bilateral bronchiectasis. Eur Respir J 2003;21:743-8.

6. Ozalp O, Inal-Ince D, Calik E, et al. Extrapulmonary features of bronchiectasis: muscle function, exercise capacity, fatigue, and health status. Multidiscip Respir Med 2012; 7: 3.

7. Pasteur MC, Bilton D, Hill AT. British Thoracic Society guideline for non CF bronchiectasis. Thorax 2010;65: 1-58.

8. Chalmers JD, Aliberti S, Blasi F. Management of bronchiectasis in adults. Eur Respir J 2015; 45: 1446-62.

9. Rosen MJ. Chronic cough due to bronchiectasis. ACCP evidence-based clinical practice guidelines. Chest 2006; 129:122-31.

10. McDonnell MJ, Ward C, Lordan JL, et al. Non-cystic fibrosis bronchiectasis. QJM 2013;106:709-15.

11. Martínez-García MA, Soriano JB. Physiotherapy in 
bronchiectasis: we have more patients, we need more evidence. Eur Respir J 2009;34:1011-2.

12. Thompson CS, Harrison S, Ashley J, et al. Randomised crossover study of the Flutter device and the active cycle of breathing technique in non-cystic fibrosis bronchiectasis. Thorax 2002;57:446-8.

13. Patterson JE, Bradley JM, Hewitt O, et al. Airway clearance in bronchiectasis: a randomized crossover trial of active cycle of breathing techniques versus Acapella. Respiration 2005;72: 239-42.

14. Eaton T, Young P, Zeng I, et al. A randomized evaluation of the acute efficacy, acceptability and tolerability of flutter and active cycle of breathing with and without postural drainage in non-cystic fibrosis bronchiectasis. Chron Respir Dis 2007;4:23-30.

15. Tsang S, Jones A. Postural drainage or flutter device in conjunction with breathing and coughing compared to breathing and coughing alone in improving secretion removal and lung function in patients with acute exacerbation of bronchiectasis: a pilot study. Hong Kong Physiother J 2003; 21: 29-36

16. Patterson JE, Hewitt O, Kent L, et al. Acapella versus 'usual airway clearance' during acute exacerbation in bronchiectasis: a randomized crossover trial. Chron Respir Dis 2007;4:67-74.

17. Murray MP, Pentland JL, Hill AT. A randomised crossover trial of chest physiotherapy in non-cystic fibrosis bronchiectasis. Eur Respir J 2009;34:1086-92.

18. Guimarães FS, Moço VJ, Menezes SL, et al. Effects of ELTGOL and Flutter VRP1 ${ }^{\circledR}$ on the dynamic and static pulmonary volumes and on the secretion clearance of patients with bronchiectasis. Rev Bras Fisioter 2012;16:108-13.

19. Munoz G, De Gracia J, Bruxo' M, et al. Long term benefits of airway clearance in bronchiectasis: a randomized placebo control trial. Eur Respir J 2018;51:1701926.

20. Abdelhalim HA, Aboelnaga HH, Fathy KA. Comparison between active cycles of breathing with postural drainage versus conventional chest physiotherapy in subjects with bronchiectasis. Egypt J Chest Dis Tuberc 2016;65:157-65.

21. Syed N, Maiya AG, Siva Kumar T. Active cycles of breathing technique (ACBT) versus conventional chest physical therapy on airway clearance in bronchiectasis - a crossover trial. Adv Physiother 2009;11:193-8.

22. Naraparaju S, Vaishali K, Venkatesan P, et al. A comparison of the Acapella and a threshold inspiratory muscle trainer for sputum clearance in bronchiectasis-A pilot study. Physiother Theory Pract 2010;26:353-7.

23. Venturelli E, Crisafulli E, DeBiase A, et al. Efficacy of temporary positive expiratory pressure (TPEP) in patients with lung diseases and chronic mucus hypersecretion. The UNIKO ${ }^{\circledR}$ project: a multicentre randomized controlled trial. Clin Rehabil 2013;27:336-46.

24. Herrero-Cortina B, Vilaro J, Marti D, et al. Short-term effects of three slow expiratory airway clearance techniques in patients with bronchiectasis: a randomised crossover trial. Physiotherapy 2016;102:357-64.

25. D'Abrosca F, Garabelli B, Savio G, et al. Comparing airways clearance techniques in chronic obstructive pulmonary disease and bronchiectasis: positive expiratory pressure or temporary positive expiratory pressure? A retrospective study. Braz Phys Ther 2017;21:15-23.

26. Nicolini A, Cardini F, Landucci N, et al. Effectiveness of treatment with high-frequency chest wall oscillation in patients with bronchiectasis. BMC Pulm Med 2013; 13:21.

27. Paneroni M, Clini E, Simonelli C, et al. Safety and efficacy of short-term intrapulmonary percussive ventilation in patients with bronchiectasis. Respir Care 2011;56:984-8.

28. Valente AM, Gastaldi AC, Cravo SL, et al. The effect of two tecniques on the characteristics and trasport of sputum in patient with bronchiectasis. A pilot study. Physiotherapy 2004;90:158-64.

29. Tambascio J, de Souza LT, Lisboa RM, et al. The influence of Flutter®VRP1 components on mucus transport of patients with bronchiectasis. Respir Med 2011;105:1316-21.

30. Figueiredo PH, Zin WA, Guimarães FS. Flutter valve improves respiratory mechanics and sputum production in patients with bronchiectasis. Physiother Res Int 2012;17:12-20.

31. Ramos EM, Ramos D, Moreira GL, et al. Viscoelastic properties of bronchial mucus after respiratory physiotherapy in subjects with bronchiectasis. Respir Care2015;60:724-30.

32. Conway JH, Fleming JS, Perring S, et al. Humidification as an adjunct to chest physiotherapy in aiding tracheo-bronchial clearance in patients with bronchiectasis. Respir Med 1992;86:109-14.

33. Hasani A, Chapman TH, McCool D, et al. Domiciliary humidification improves lung mucociliary clearance in patients with bronchiectasis. Chron Respir Dis 2008;5:81-6.

34. Rea H, McAuley S, Jayaram L, et al. The clinical utility of longterm humidification therapy in chronic airway disease. Respir Med 2010;104:525-33.

35. McKenzie DK, Frith PA, Burdon JG, et al. The COPDX Plan: Australian and New Zealand Guidelines for the management of Chronic Obstructive Pulmonary Disease 2003. Med J Aust 2003;178: 7-39

36. Kellett F, Redfern J, Niven RM. Evaluation of nebulised hypertonic saline $(7 \%)$ as an adjunct to physiotherapy in patients with stable bronchiectasis. Respir Med 2005;99:27-31.

37. Kellett F, Robert NM. Nebulised 7\% hypertonic saline improves lung function and quality of life in bronchiectasis. Respir Med 2011;105:1831-5.

38. Nicolson CH, Stirling RG, Borg BM, et al. The long term effect of inhaled hypertonic saline $6 \%$ in non-cystic fibrosis bronchiectasis. Respir Med 2012;106:661-7.

39. Newall C, Stockley RA, Hill SL. Exercise training and inspiratory muscle training in patients with bronchiectasis. Thorax 2005;60:943-8.

40. Ong HK, Lee AL, Hill CJ, et al. Effects of pulmonary rehabilitation in bronchiectasis: A retrospective study. Chron Respir Dis 2011;8:21-30.

41. Van Zeller M, Mota PC, Amorim A, et al. Pulmonary rehabilitation in patients with bronchiectasis: pulmonary function, arterial blood gases, and the 6-minute walk test. J Cardiopulm Rehabil Prev 2012;32:278-83.

42. Zanini A, Aiello M, Adamo D, et al. Effects of pulmonary rehabilitation in patients with non-cystic fibrosis bronchiectasis: A Retrospective analysis of clinical and functional predictors of efficacy. Respiration 2015;89:525-33.

43. Mandal P, Sidhu MK, Kope L, et al. A pilot study of pulmonary rehabilitation and chest physiotherapy versus chest physiotherapy alone in bronchiectasis. Respir Med 2012;106: 1647-54.

44. Lee AL, Hill CJ, Cecins N, et al. The short and long term effects of exercise training in non-cystic fibrosis bronchiectasis - a randomized controlled trial. Respir Res 2014 15;15:44.

45. Liaw MY, Wang YH, Tsai YC, et al. Inspiratory muscle training in bronchiectasis patients: a prospective randomized controlled study. Clin Rehabil 2011;25:524-36.

46. Lee AL, Burge A, Holland AE. Airway clearance techniques for bronchiectasis. Cochrane Database Syst Rev 2015; CD008351. 
47. Flude LJ, Agent P, Bilton D. Chest physiotherapy techniques in bronchiectasis. Clin Chest Med 2012;33:351-61.

48. Welsh EJ, Evans DJ, Fowler SJ, Spencer S. Interventions for bronchiectasis: an overview of Cochrane systematic reviews. Cochrane Database Syst Rev 2015. doi: 10.1002/ 14651858.CD010337.pub2

49. Snijders D, Fernandez Domingez B, Calgaro S, et al. Mucociliary clearance techniques for treating non-cystic fibrosis bronchiectasis: Is there evidence?. Int $\mathrm{J}$ Immunopathol Pharmacol 2015;28:150-9.

50. Lee AL, Williamson HC, Lorensini S, Spencer LM. The effects of oscillating positive expiratory pressure therapy in adults with stable non-cystic fibrosis bronchiectasis: A systematic review. Chron Respir Dis 2015;12:36-46.

51. Bradley J, Moran F, Greenstone M. Physical training for bronchiectasis. Cochrane Database Syst Rev 2002;CD002166.

52. Gale NS, Bolton CE, Duckers JM, et al. Systemic comorbidities in bronchiectasis. Chron Respir Dis 2012;9:231-8.

53. Lee AL, Hill CJ, McDonald CF, Holland AE. Pulmonary rehabilitation in individuals with none Cystic Fibrosis Bronchiectasis: A systematic review. Arch Phys Med Rehabil 2017;98:774-82.

54. Baldwin DR, Hill AL, Peckham DG, Knox AJ. Effect of addition of exercise to chest physiotherapy on sputum expectoration and lung function in adults with cystic fibrosis. Respir Med 1994;88:49-53.

55. Aliberti S, Mesefield S, Polverino E, et al. Research priorities in bronchiectasis: a consensus statement from the EMBARC Clinical Research Collaboration. Eur Respir J 2016;48:632-47 